Technical Article

\title{
Leaf spots of calibrachoa caused by Nigrospora oryzae
}

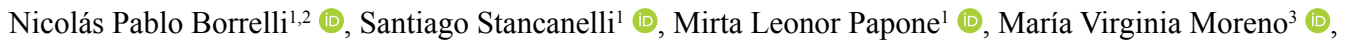

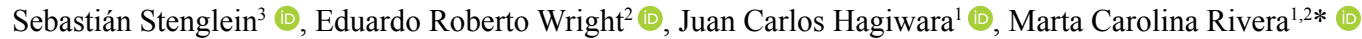

\author{
${ }^{1}$ Instituto Nacional de Tecnología Agropecuaria, Instituto de Floricultura, Hurlingham, Buenos Aires, Argentina. \\ ${ }^{2}$ Universidad de Buenos Aires, Facultad de Agronomía, Departamento de Producción Vegetal, Ciudad de Buenos Aires, Argentina. \\ ${ }^{3}$ CONICET-INBIOTEC, UNCPBA-CICBA. Laboratorio de Biología Funcional y Biotecnología (BIOLAB). Facultad de Agronomía, \\ Área de Microbiología, Azul, Buenos Aires, Argentina.
}

\begin{abstract}
Calibrachoa hybrida (calibrachoa, million bells) is a flowering ornamental with increasing importance due to the existence of many successful cultivars for growing indoors in containers and planting in the garden and landscape. The outstanding characteristic is a profuse flowering and intense colour. In October 2019, a fungal isolate was obtained from basal calibrachoa leaves with irregular brown leaf spots, in plants cultivated in Buenos Aires, Argentina. The aim of the present study was to identify the cause of the disease in this ornamental genus, to expand knowledge about prevalent pathologies. The isolate was identified using morphological and molecular markers, and the pathogenicity tests were fulfilled. This paper reports that Nigrospora oryzae is pathogenic to calibrachoa, which seems to be the first record of this leaf spot disease in the world.
\end{abstract}

Keywords: Calibrachoa hybrida, fungal disease, fungus, ornamental plants, pathogenicity.

\section{Resumo}

Manchas foliares em calibrachoa causadas por Nigrospora oryzae

Calibrachoa hybrida (calibrachoa ou falsa-petúnia) é uma planta ornamental com importância crescente no mercado devido a existência de inúmeras variedades que podem ser cultivadas em vasos, jardins e paisagismo. A característica marcante é sua floração abundante e de cores vibrantes. Em outubro de 2019, foi obtido um isolado de fungo em folhas basais de calibrachoa, com manchas foliares marrons e irregulares, em plantas cultivadas em Buenos Aires, Argentina. O objetivo do presente estudo foi identificar o agente causal das manchas foliares em calibrachoa para expandir o conhecimento sobre as doenças prevalentes nesta importante planta ornamental. O isolado foi identificado por meio de marcadores morfológicos e moleculares, bem como a sua patogenicidade foi comprovada por meio do postulado de Koch. O fungo foi identificado como Nigrospora oryzae, sendo que presente artigo, além de relatar a sua patogenicidade, parece ser o primeiro registro desta doença em calibrachoa no mundo.

Palavras-chave: Calibrachoa hybrida, doença fúngica, fungo, patogenicidade, plantas ornamentais.

\section{Introduction}

Calibrachoa Cerv. is a Neotropical genus of Solanaceae belonging to the clade Petunieae. It comprises 27 species predominantly found in open areas of southern South America (Fregonezi et al., 2012). Most of the species occur in Brazil (Stehmann and Greppi, 2011) and 12 of them grow in Argentina, mostly in the east of the Mesopotamic region (Fregonezi et al., 2012; Greppi et al., 2013). Some species are currently threatened because of anthropic impact (John et al., 2019). This ornamental genus has increasing importance due to the existence of many successful varieties for growing indoors in containers and planting in the garden and landscape. The outstanding characteristic is a profuse flowering and intense colour (Facciuto et al., 2009).

One of the main goals in ornamental horticulture is the production of cultivars with new characteristics such as novel flower colour and plant architecture (Azadi et al., 2016). However, despite the great diversity and potential of flora present in South America there has been poor local development of ornamental cultivars derived from it (Bugallo et al., 2011). For this reason, breeding carried out at the Instituto de Floricultura INTA (Instituto Nacional de

"Corresponding author: mrivera@agro.uba.ar 
Tecnología Agropecuaria) has been focused on obtaining hybrids from germplasm native to Argentina. The genus Calibrachoa is included in those breeding programs, as a result of which the cultivars Pampa Salmón - INTA and Overá Fucsia - INTA were registered for the local market, and INTA 06575 (Superbells ${ }^{(\mathrm{R})}$ Garden Rose) for North American market. These are evergreen sub-shrubs with brightly coloured flowers, usually called calibrachoas, million bells or mini petunias.

To date, Calibrachoa mottle virus (CbMV) (Liu et al., 2003), Tobacco mild green mosaic virus (TMGMV) (Sabanadzovic et al., 2009), Podosphaera xanthii (Brielmaier-Liebetanz et al., 2015), Phytophthora nicotianae (Lin et al., 2018), Potato virus Y (PVY) (Tombion et al., 2019), Alternaria porri (Nishikawa and
Nakashima, 2020), and Sclerotinia sclerotiorum (Borrelli et al., 2020), have been reported to infect calibrachoa plants in different countries. The development of new cultivars includes disease surveys. Calibrachoas with good nutrition and no stress are usually less affected by diseases. However, aerial symptoms appeared on cultivar INTA 06575 while others grown in the same greenhouse were healthy. The aim of this work was to identify the cause of the disease.

\section{Materials and Methods}

In October 2019, plants of calibrachoa INTA 06575 (Figure 1) grown in a polyethylene greenhouse in Hurlingham (Buenos Aires) developed a leaf spot disease.

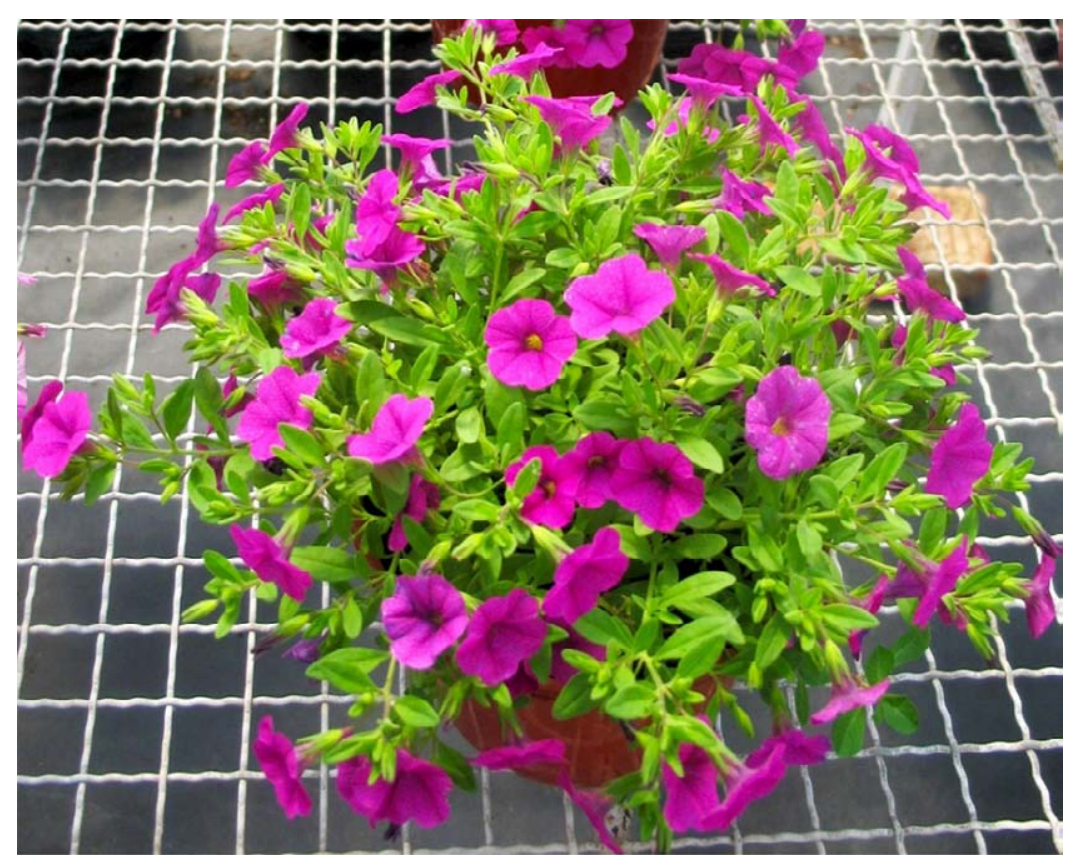

Figure 1. Healthy potted plant of Calibrachoa hybrida INTA 06575 on a greenhouse bench.

The lesions were brown, of irregular forms, with mean dimensions of $6 \mathrm{~mm} \times 2 \mathrm{~mm}$, and appeared on the basal leaves of the plants (Figure 2). Sections of symptomatic leaves were surface disinfected in $70 \%$ ethanol for one minute and bleach (20 $\mathrm{g} \mathrm{Cl} \mathrm{L}^{-1}$ water) for other minute, rinsed in sterile distilled water and cultured on $2 \%$ potato dextrose agar (PDA). The plates were incubated at $22{ }^{\circ} \mathrm{C}$ for 5 days. 


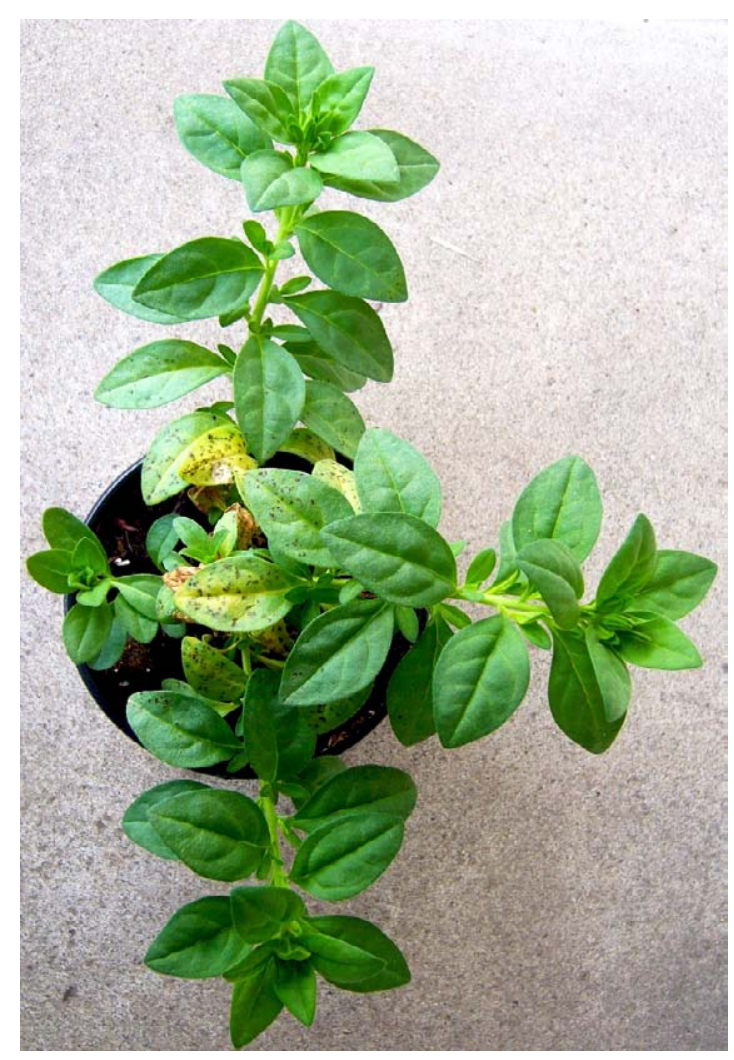

Figure 2. Spots caused by Nigrospora oryzae on basal leaves of Calibrachoa hybrida INTA 06575.

The fungal colonies developed from the leaves were subcultured onto fresh PDA at $25^{\circ} \mathrm{C}$ to obtain a pure isolate, and study its characteristics. To enhance sporulation, $5 \mathrm{~mm}$ diameter plugs from the margin of an actively growing culture were transferred to the centre of Petri dishes containing synthetic nutrient-poor agar medium (SNA) and incubated at $28{ }^{\circ} \mathrm{C}$ (Wang et al., 2017). Additionally, in order to better clarify the identity of the pathogen, a molecular characterization of the purified isolate was performed amplifying and sequencing part of the ITS rDNA region using primers ITS1 and ITS4 (Wang et al., 2017). The sequence obtained in this study was submitted to GenBank (accession number MT177215) and the nucleotide BLAST comparison with published sequences at NCBI (http://www.ncbi.nlm.nih.gov/).

Twenty-four healthy potted plants of calibrachoa INTA 06575 were obtained by asexual propagation, for further studies of pathogenicity. When the plants were 2-month old, twelve of them were sprayed with suspensions of $N$. oryzae $\left(1 \times 10^{5}\right.$ conidia $\left.\mathrm{mL}^{-1}\right)$ prepared from 14-day-old colonies of the pure isolate on PDA. The control treatment consisted of twelve plants that were sprayed with sterilized distilled water. The plants were enclosed individually in polyethylene bags, and placed in a greenhouse at $24{ }^{\circ} \mathrm{C}$. The bags were removed after $72 \mathrm{~h}$.

\section{Results and Discussion}

A hyphomycete matching the genus Nigrospora developed from the leaves, and it was coded as INTAIF-540. On PDA, the isolate developed floccose colonies that were initially white and later turned greyish reaching $9 \mathrm{~cm}$ diameter in 7 days (Figures 3A-B). After 7 days of cultivation on SNA, the colonies were initially white (Figures 3C-D), turned dark brown to black with abundant aerial mycelia, and reached $8.1 \mathrm{~cm}$ in 7 days. The onset of sporulation occurred at day 10. The hyphae were branched, septate, smooth and hyaline, becoming brown closer to the conidiogenous cells. The conidiophores (1.9-)3.4(-6.5) $\mu \mathrm{m}$, were aggregated in dark sporodochia (Figure 3E) and the hyaline conidiogenous cells were monoblastic, determinate and ampulliform (4,2)6.5(-8,7) x $(3,4-) 6.1(-9,8) \mu \mathrm{m}$. Abundant single-celled subglobose black conidia were formed (11.9-)13.7(-16.0) x $(8,8-) 12.4(-14,8) \mu \mathrm{m}$ (Figure 3F). 

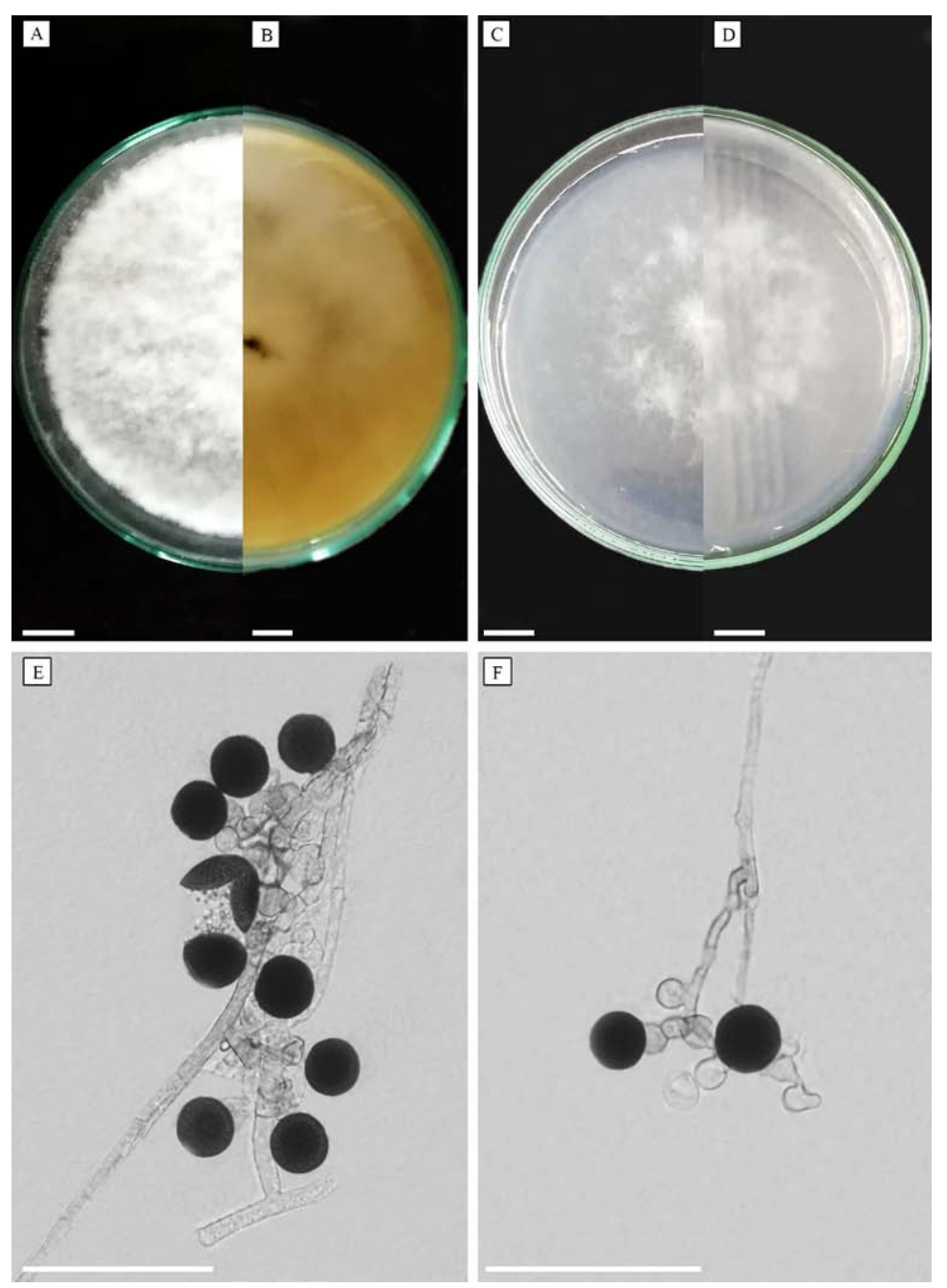

Figure 3. Cultures of Nigrospora oryzae. A-B. top and bottom views on PDA; C-D. top and bottom views on SNA $($ scale bars $=1 \mathrm{~cm})$; E. sporodochia; F. conidia (scale bars $=50 \mu \mathrm{m})$.

A teleomorph state was not observed. The morphology of the isolate matched Nigrospora oryzae (Wang et al., 2017), and a monoconidial isolate was deposited in the Entomopathogenic Fungal Culture Collection of Argentina as CEP 786. The nucleotide BLAST comparison with published sequences at NCBI showed $100 \%$ of similarity with sequences of Nigrospora oryzae (ex. EU529994, MG182683).
Five days after inoculation some areas of the basal leaves appeared slightly sunken, and were discoloured and shiny in two days more. Those whitish areas turned into light brown in another 2 days. Fully developed spots were irregular, with brown sunken centres with or without dark margins 15 days after inoculation (Figure 4). 


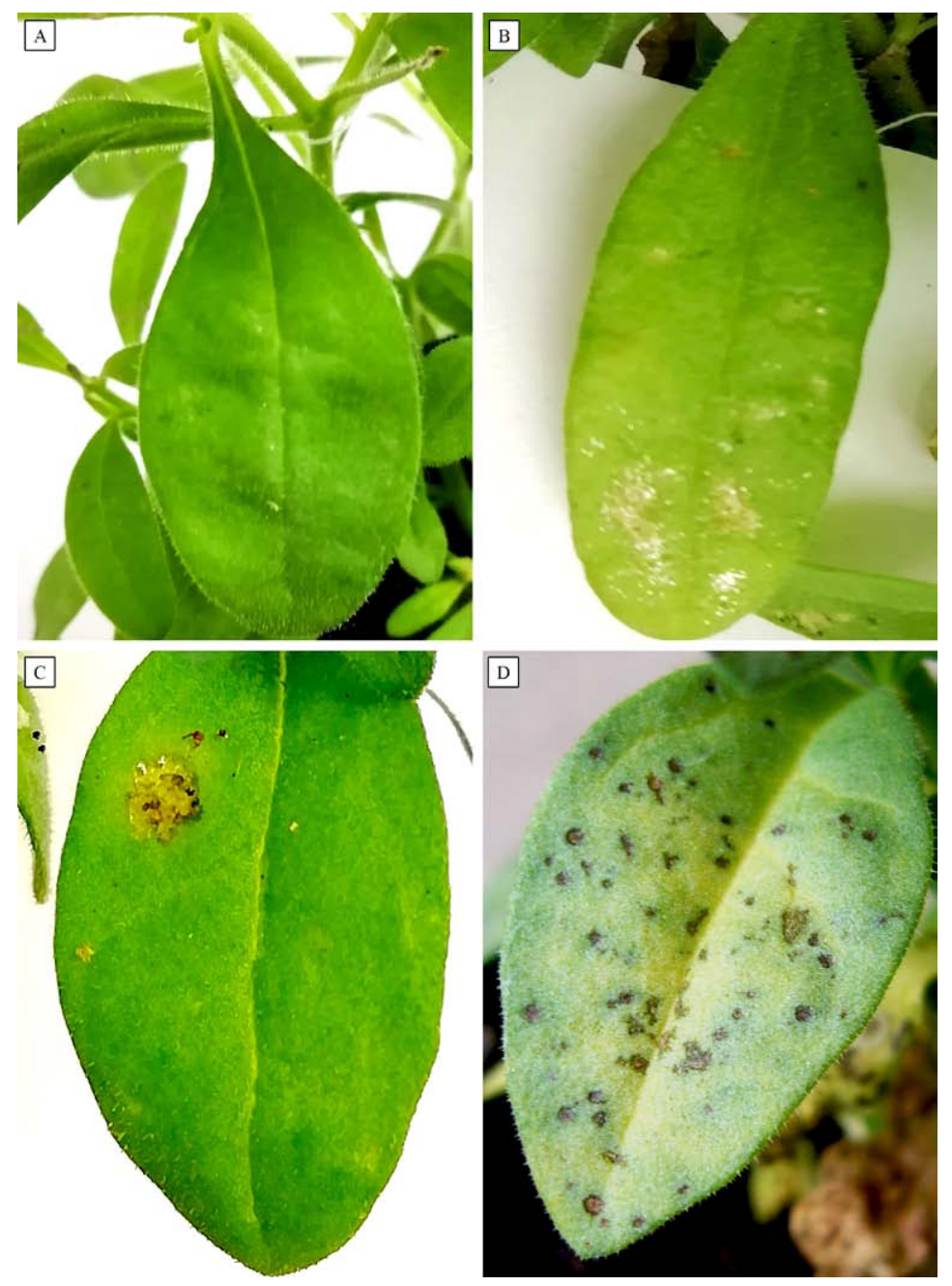

Figure 4. Development of leaf spots caused by Nigrospora oryzae on inoculated leaves of Calibrachoa hybrida. A. slightly sunken leaf areas; B. discoloured and shiny spots; C. light brown spots; D. fully developed leaf spots.

The apical leaves of the inoculated plants as well as all the leaves of the controls remained healthy. The fungal isolate was re-isolated, thus fulfilling Koch's postulatesand confirming that it is pathogenic to calibrachoa. Nigrospora oryzae was reported as pathogenic on 134 hosts of different economic importance around the world (Farr and Rossman, 2020). Our results add a new species to the increasing host list of $N$. oryzae. Although calibrachoa is popular as a potted plant crop in many regions, little is known about the diseases these plants may develop, maybe because it is a relatively new crop. Among the pathogens previously reported on calibrachoa, only $A$. porri causes leaf spots (Nishikawa and Nakashima, 2020). The symptoms were not described but Alternaria leaf spots on many plants are clearly distinct from the ones we found associated with $N$. oryzae in calibrachoa.

World's ornamental plant market is expanding with a remarkable dynamism and a constant need for innovation (Botelho et al., 2015). New hybrids have often been developed with focus on flower shape and size (Jędrzejuk, et al., 2017), as the ones derived from the genus Calibrachoa. The identification of their pathogens is the basis for the development of plant protection programs. As a result of this work, a leaf spot disease caused by $N$. oryzae was observed and confirmed on calibrachoa cv. INTA 06575, thus enlarging knowledge on calibrachoa diseases. Further research is needed to characterize the response of Calibrachoa species and cultivars to the inoculation with the pathogen.

\section{Conclusions}

This is the first report of Nigrospora oryzae on Calibrachoa hybrida. The disease is characterized by the development of leaf spots.

\section{Author Contribution}

NPB: Conception and design of the work, material preparation, acquisition, analysis, and interpretation of data, draft of the manuscript, Figure edition. SS: Material preparation, acquisition, analysis, and interpretation of data, resources. M.P: Material preparation, acquisition, analysis, and interpretation of data, critical revision. MVM: Material preparation, acquisition, 
analysis, and interpretation of data, resources, draft of the manuscript and critical revision. SS: Material preparation, acquisition, analysis, and interpretation of data, resources, drafting the manuscript and critical revision. ERW: Acquisition, analysis, and interpretation of data, critical revision, funds acquisition. JCH: Acquisition, analysis, and interpretation of data, critical revision of the manuscript. MCR: Conception and design of the work, acquisition, analysis, and interpretation of data, drafting the manuscript and revising it critically for important intellectual content, funding acquisition and supervision.

\section{Acknowledgments}

This work was supported by Instituto Nacional de Tecnología Agropecuaria (INTA I140), Agencia Nacional de Promoción Científica y Técnica (PICT 2016-2589) and Universidad de Buenos Aires (UBACYT 20020160100066BA).

\section{References}

AZADI, P.; BAGHERI, H.; NALOUSI, A.M.; NAZARI, F.; CHANDLER, S.F. Current status and biotechnological advances in genetic engineering of ornamental plants. Biotechnology Advances, v.34, n.6, p.1073-1090, 2016. DOI: https://doi.org/10.1016/j.biotechadv.2016.06.006

BORRELLI, N.P.; PAPONE, M.L.; MORENO, M.V.; STENGLEIN, S.; STANCANELLI, S., WRIGHT, E.R., HAGIWARA, J.C.; RIVERA, M.C. First report of basal rot caused by Sclerotinia sclerotiorum on Calibrachoa hybrida. Plant Disease, 2020. DOI: https://doi.org/10.1094/PDIS04-20-0767-PDN

BOTELHO, F.B.S.; SOUZA RODRIGUES, C.; BRUZI, A.T. Ornamental plant breeding. Ornamental Horticulture, v.21, n.1, p.9-16, 2015. DOI: https://doi. org/10.14295/rbho.v21i1.770

BRIELMAIER-LIEBETANZ, U.; FIELD, A.E; WARFIELD, C.Y; BRAUN, U. Powdery mildew (Erysiphaceae) on Calibrachoa hybrids in Germany, Nicaragua and the USA. Plant Pathology \& Quarantine, v.5, n.1, p.1-5, 2015. DOI: http://dx.doi.org/10.5943/ $\mathrm{ppq} / 5 / 1 / 1$

BUGALLO, V.; CARDONE, S.; PANNUNZIO, M.J.; FACCIUTO, G. Breeding advances in Passiflora (passionflower) native from Argentina. Floriculture and Ornamental Biotechnology, v.5, n.1, p.23-34, 2011.

JOHN, A.L. de W.; MÄDER, G.; FREGONEZI, J.N.; FREITAS, L.B. Genetic diversity and population structure of naturally rare Calibrachoa species with small distribution in southern Brazil. Genetics and Molecular Biology, v.42, n.1, p.108-119, 2019. DOI: http://dx.doi. org/10.1590/1678-4685-gmb-2017-0314
FACCIUTO, G.; PANNUNZIO, M.J.; COVIELLA, A.; BOLOGNA, P.; SOTO, S.; IMHOF, L.; BORJA, M. Calibrachoa breeding advances in Argentina. Acta Horticulturae, n.813, p.121-126, 2009. DOI: 10.17660/ ActaHortic.2009.813.15

FARR, D.F.; ROSSMAN, A.Y. 2020. Fungal Databases - U.S. National Fungus Collections, ARS, USDA. Available at: <https://nt.ars-grin.gov/fungaldatabases/>. Accessed on: August 20 $0^{\text {th }}, 2020$.

FREGONEZI, J.N.; BRANDÃO DE FREITAS, L.; BONATTO, S.L.; SEMIR, J.; STEHMANN, J.R. Infrageneric classification of Calibrachoa (Solanaceae) based on morphological and molecular evidence. Taxon, v.61, n.1, p.120-130, 2012. DOI: https://doi.org/10.1002/tax.611009

GREPPI, J.A.; HAGIWARA, J.C.; STEHMANN, J.R. Novelties in Calibrachoa (Solanaceae) and taxonomic notes on the genus for Argentina. Darwiniana nueva serie, v.1, p.173-187, 2013.

JĘDRZEJUK, A.; MEYER, L.; SEREK, M. Characterization of interspecific hybrids of Petuniaand Calibrachoa by multiplex PCR, DNA content, and chromosome number. The Journal of Horticultural Science and Biotechnology, v.92, n.5, p.493-501, 2017. DOI: $10.1080 / 14620316.2017 .1288554$

LIN, S.; MARTIN, D.E.; TAYLOR, N.J.; GABRIEL, C.K.; DEVI GANESHAN, V.; PEDUTO HAND F. First report of Phytophthora aerial blight caused by Phytophthora nicotianae on vinca, lobelia, and calibrachoa in Ohio. Plant Disease, v.102, n.2, 2018. DOI: https://doi.org/10.1094/ PDIS-07-17-1057-PDN

LIU, H.Y.; SEARS, J.L; MORRISON, R.H. Isolation and characterization of a carmo-like virus from Calibrachoa plants. Plant Disease, v.87, n.2, p.167-171, 2003. DOI: https://doi.org/10.1094/PDIS.2003.87.2.167

NISHIKAWA, J.; NAKASHIMA, C. Japanese species of Alternaria and their species boundaries based on host range. Fungal Systematics and Evolution, v.5, p.197-281, 2020 DOI: $10.3114 /$ fuse.2020.05.13

SABANADZOVIC, S; HENN, A; ABOU GHANEMSABANADZOVIC, N; LAWRENCE, A. First report on Tobacco mild green mosaic virus in calibrachoa plants (Calibrachoa $\times$ hybrida) in Mississippi. Plant Disease, v.93, n.12, p.1354, 2009. DOI: https://doi.org/10.1094/ PDIS-93-12-1354A

STEHMANN, J.R.; GREPPI, J.A. Two new species of Calibrachoa (Solanaceae) from subtropical South America. Phytotaxa, v.25, p.31-38, 2011. DOI: https://doi. org/10.11646/phytotaxa.25.1.4 
TOMBION, L.; ALDERETE, L.M.; PEREZ DE LA WANG, M.; LIU, F.; CROUS, P.W.; CAI, L. Phylogenetic TORRE, M.; AGROFOGLIO, Y.C.; DELFOSSE, V.C.; reassessment of Nigrospora: ubiquitous endophytes, plant DISTEFANO, A.J.; SOTO, M.S. First report of Potato and human pathogens. Persoonia, v.39, p.118-142, 2017. virus $Y$ in ornamental Calibrachoa in Argentina. Plant Disease, v.103, n.7, 2019. DOI: https://doi.org/10.1094/ DOI: https://doi.org/10.3767/persoonia.2017.39.06 PDIS-09-18-1673-PDN 